\title{
Preface: "Improving seismic networks performances: from site selection to data integration" (EGU2015 SM1.2/GI1.5 session)
}

\author{
D. Pesaresi ${ }^{1}$, H. Pedersen ${ }^{2}$, and Y. Starovoit ${ }^{3}$ \\ ${ }^{1}$ OGS (Istituto Nazionale di Oceanografia e di Geofisica Sperimentale), Trieste, Italy \\ ${ }^{2}$ RESIF (Réseau sismologique \& géodésique français), Grenoble, France \\ ${ }^{3}$ CTBTO (Comprehensive Nuclear-Test-Ban Treaty Organization), Vienna, Austria
}

Correspondence to: D. Pesaresi (dpesaresi@inogs.it)

\begin{abstract}
The number and quality of seismic stations and networks in Europe continually improves, nevertheless there is always scope to optimize their performance. In this EGU2015 SM1.2/GI1.5 session we welcomed contributions from all aspects of seismic network installation, operation and management. This includes site selection; equipment testing and installation; planning and implementing communication paths; policies for redundancy in data acquisition, processing and archiving; and integration of different data sets including GPS and OBS.
\end{abstract}

\section{Introduction}

The history of seismic networks sessions at European Geosciences Union (EGU) general assemblies started in 2010 with the SM1.3 "Seismic Centers Data Acquisition" session (Pesaresi, 2011), where the convener Damiano Pesaresi supported by the Orfeus Data Center (ODC) Director coconvener Reinoud Sleeman chaired a session of 7 oral and 16 poster presentations. Later in the same year a similar session was held at the XXXII European Seismological Commission (ESC) General Assembly: "SD1, 3 Seismic centers data acquisition", conveners D. Pesaresi and R. Sleeman, with 15 oral presentations.

The history of these sessions continued in 2011 with the EGU2011 SM1.3/G3.8/GD3.7/GI-19/TS8.7 "Improving seismic networks performances: from site selection to data integration" session (EGU2011 SM1.3/G3.8/GD3.7/GI19/TS8.7 Improving seismic networks performances: from site selection to data integration, 2011), where the convener Damiano Pesaresi supported by the co-conveners John Clinton and Robert Busby chaired a session of 9 oral and 20 poster presentations; in 2012 with the EGU2012
SM1.3/GI1.7 "Improving seismic networks performances: from site selection to data integration" session (Pesaresi and Vernon, 2013), where the convener Damiano Pesaresi supported by the co-convener Frank Vernon chaired a session of 6 oral and 22 poster presentations; in 2013 with the SM1.4/GI1.6 "Improving seismic networks performances: from site selection to data integration" session (Pesaresi and Busby, 2013), where the convener Damiano Pesaresi supported by the co-convener Robert Busby chaired a session of 6 oral and 13 poster presentations; and in 2014 with the EGU2014 SM1.2/GI3.7 "Improving seismic networks performances: from site selection to data integration" session (Pesaresi et al., 2015), where the convener Damiano Pesaresi supported by the co-conveners John Clinton and Helle Pedersen chaired a session of 12 oral and 27 poster presentations.

\section{The EGU2015 SM1.2/GI1.5 session}

In the EGU2015 SM1.2/GI1.5 "Improving seismic networks performances: from site selection to data integration" session (EGU2015 SM1.2/GI1.5 Improving seismic networks performances: from site selection to data integration, 2015) the convener Damiano Pesaresi supported by the co-conveners Helle Pedersen and Yuri Starovoit chaired a session (Fig. 1) of 20 posters (Table 1 ).

The 20 presentations came from 13 countries (Austria, Kazakhstan, Malta, Greece, Chile, USA, France, Finland, Bulgaria, Germany, UK, Italy, Slovenia), in four continents (Europe, Asia, South America, North America), which fits well to the goals of the European Geosciences Union.

The solicited presentations in this session were the following: 
Table 1. Poster programme for the EGU2015 SM1.2/GI1.5 session.

\begin{tabular}{|c|c|c|}
\hline EGU Abstract ref. & Title & Authors \\
\hline EGU2015-1611 & $\begin{array}{l}\text { Ground Truth and Application for the Anisotropic } \\
\text { Receiver Functions Technique - Test site KTB: the } \\
\text { installation campaign }\end{array}$ & $\begin{array}{l}\text { Irene Bianchi, Mario Anselmi, Maria-Theresia } \\
\text { Apoloner, Ehsan Qorbani, Katalin Gribovszki, and } \\
\text { Götz Bokelmann }\end{array}$ \\
\hline EGU2015-3702 & $\begin{array}{l}\text { Ebreichsdorf } 2013 \text { Earthquake Series: Relative Lo- } \\
\text { cation }\end{array}$ & Maria-Theresia Apoloner and Götz Bokelmann \\
\hline EGU2015-3708 & $\begin{array}{l}\text { Modeling and Detection of Regional Depth Phases } \\
\text { at the GERESS Array }\end{array}$ & Maria-Theresia Apoloner and Götz Bokelmann \\
\hline EGU2015-4516 & $\begin{array}{l}\text { Seismic monitoring of Central Asia territory in } \\
\text { KNDC res }\end{array}$ & Aidyn Mukambayev and Natalia Mikhailova \\
\hline EGU2015-4523 & $\begin{array}{l}\text { Recent developments in the setting up of the Malta } \\
\text { Seismic Network }\end{array}$ & $\begin{array}{l}\text { Matthew Agius, Pauline Galea, and Sebastiano } \\
\text { D'Amico }\end{array}$ \\
\hline EGU2015-6232 & $\begin{array}{l}\text { The Hellenic Seismological Network Of Crete } \\
\text { (HSNC): Validation and results of the } 2013 \text { after- } \\
\text { shock sequences }\end{array}$ & $\begin{array}{l}\text { Georgios Chatzopoulos, Ilias Papadopoulos, and } \\
\text { Filippos Vallianatos }\end{array}$ \\
\hline EGU2015-7561 & $\begin{array}{l}\text { Field Installation and Real-Time Data Processing of } \\
\text { the New Integrated SeismoGeodetic System with } \\
\text { Real-Time Acceleration and Displacement Mea- } \\
\text { surements for Earthquake Characterization Based } \\
\text { on High-Rate Seismic and GPS Data }\end{array}$ & $\begin{array}{l}\text { Leonid Zimakov, Michael Jackson, Paul Passmore, } \\
\text { Jared Raczka, Marcos Alvarez, and Sergio Barrien- } \\
\text { tos }\end{array}$ \\
\hline EGU2015-7985 & $\begin{array}{l}\text { Comparative Noise Performance of Portable Broad- } \\
\text { band Sensor Emplacements }\end{array}$ & $\begin{array}{l}\text { Justin Sweet, Eliana Arias-Dotson, Bruce Beau- } \\
\text { doin, and Kent Anderson }\end{array}$ \\
\hline EGU2015-9164 & $\begin{array}{l}\text { Sources of high frequency seismic noise: insights } \\
\text { from a dense network of } \sim 250 \text { stations in northern } \\
\text { Alsace (France) }\end{array}$ & $\begin{array}{l}\text { Jerome Vergne, Antoine Blachet, Maximilien Lehu- } \\
\text { jeur and the EstOF Team }\end{array}$ \\
\hline EGU2015-9965 & $\begin{array}{l}\text { AlpArray Austria - Illuminating the subsurface of } \\
\text { Austria and understanding of Alpine geodynamics }\end{array}$ & $\begin{array}{l}\text { Florian Fuchs, Götz Bokelmann, Irene Bianchi, } \\
\text { Maria-Theresia Apoloner, and AlpArray Working } \\
\text { Group }\end{array}$ \\
\hline EGU2015-11264 & $\begin{array}{l}\text { Automatic data processing and analysis system for } \\
\text { monitoring region around a planned nuclear power } \\
\text { plant }\end{array}$ & $\begin{array}{l}\text { Timo Tiira, Outi Kaisko, Jari Kortström, Tommi } \\
\text { Vuorinen, Marja Uski, and Annakaisa Korja }\end{array}$ \\
\hline EGU2015-11506 & $\begin{array}{l}\text { Automatic classification of seismic events within a } \\
\text { regional seismograph network }\end{array}$ & Timo Tiira, Jari Kortström, and Marja Uski \\
\hline EGU2015-11525 & $\begin{array}{l}\text { Introduction of digital object identifiers (DOI) for } \\
\text { seismic networks }\end{array}$ & $\begin{array}{l}\text { Peter Evans, Angelo Strollo, Adam Clark, Tim Ah- } \\
\text { ern, Rob Newman, John Clinton, Catherine Pequeg- } \\
\text { nat, and Helle Pedersen }\end{array}$ \\
\hline EGU2015-11614 & $\begin{array}{l}\text { Local network deployed around the Kozloduy NPP } \\
\text { - a useful tool for seismological monitoring }\end{array}$ & $\begin{array}{l}\text { Dimcho Solakov, Stela Simeonova, Liliya Dim- } \\
\text { itrova, Krasimira Slavcheva, Plamena Raykova, } \\
\text { Maria Popova, and Ivan Georgiev }\end{array}$ \\
\hline EGU2015-12129 & $\begin{array}{l}\text { Preliminary performance report of the RHUM- } \\
\text { RUM OBS network }\end{array}$ & $\begin{array}{l}\text { Simon C. Stähler, Wayne Crawford, Guilhem Bar- } \\
\text { ruol, Karin Sigloch, and Schmidt-Aursch Mechita }\end{array}$ \\
\hline EGU2015-12279 & The Austrian National Network 2014 & Nikolaus Horn, Helmut Hausmann, and Yan Jia \\
\hline EGU2015-12334 & $\begin{array}{l}\text { "SeismoSAT" project results in connecting seismic } \\
\text { data centres via satellite }\end{array}$ & $\begin{array}{l}\text { Damiano Pesaresi, Wolfgang Lenhardt, Markus } \\
\text { Rauch, Mladen Živčić, Rudolf Steiner, Michele } \\
\text { Bertoni, and Heimo Delazer }\end{array}$ \\
\hline EGU2015-13196 & $\begin{array}{l}\text { Seismic noise recorded by seafloor observatories at } \\
\text { Mediterranean sites }\end{array}$ & $\begin{array}{l}\text { Mariagrazia De Caro, Stephen Monna, Francesco } \\
\text { Frugoni, Laura Beranzoli, and Paolo Favali }\end{array}$ \\
\hline EGU2015-14387 & $\begin{array}{l}\text { Impact of sensor installation techniques on seismic } \\
\text { network performance }\end{array}$ & $\begin{array}{l}\text { Geoffrey Bainbridge, Michael Laporte, Dario Batu- } \\
\text { ran, and Wesley Greig }\end{array}$ \\
\hline EGU2015-14813 & $\begin{array}{l}\text { UMTS rapid response real-time seismic networks: } \\
\text { implementation and strategies at INGV }\end{array}$ & $\begin{array}{l}\text { Aladino Govoni, Lucia Margheriti, Milena Moretti, } \\
\text { Valentino Lauciani, Gianpaolo Sensale, Augusto } \\
\text { Bucci, and Fabio Criscuoli }\end{array}$ \\
\hline
\end{tabular}




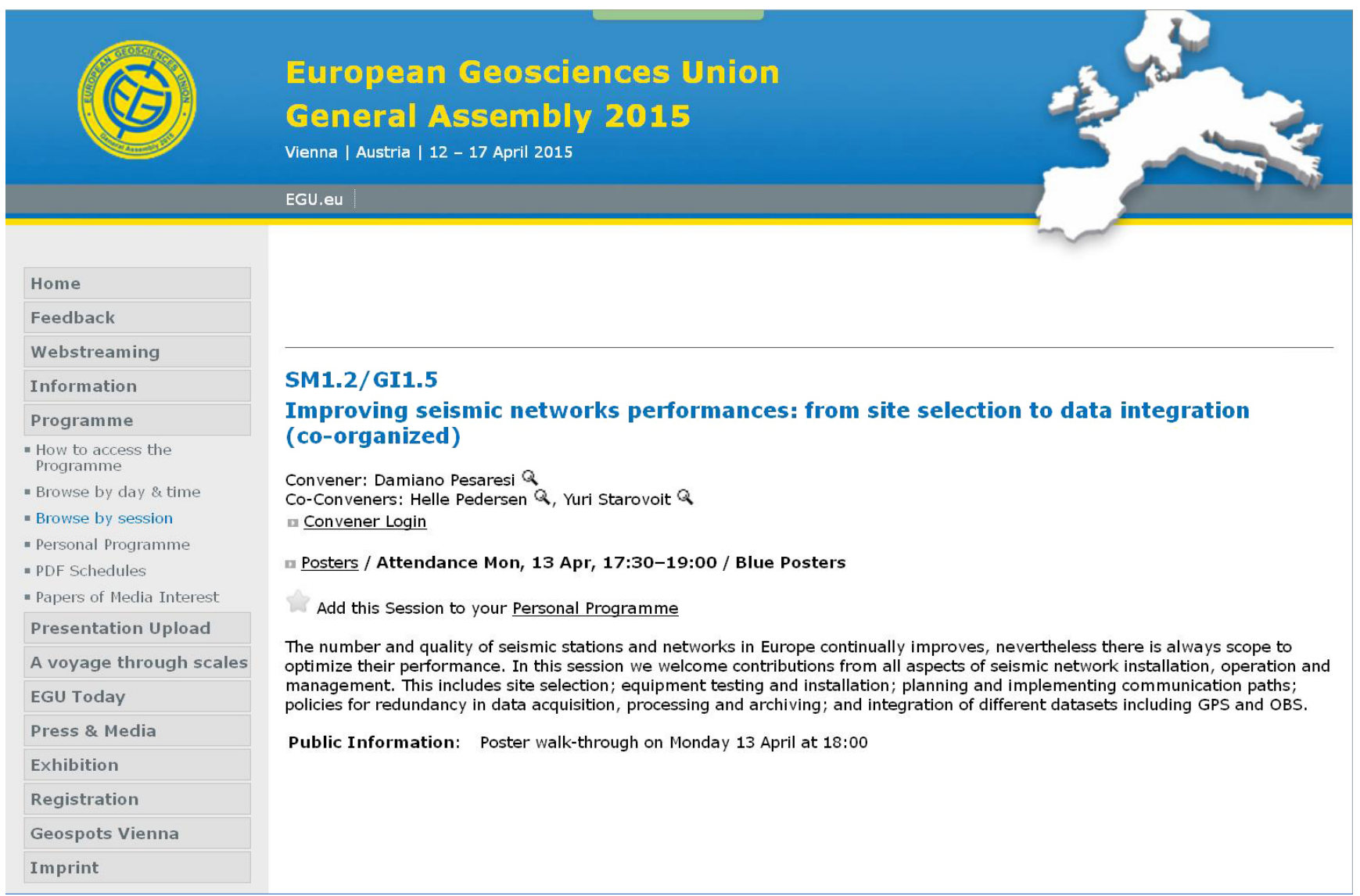

Figure 1. EGU2015 SM1.2/GI1.5 session (from the EGU2015 home page).

i. "Comparative Noise Performance of Portable Broadband Sensor Emplacements", by Justin Sweet, Eliana Arias-Dotson, Bruce Beaudoin, and Kent Anderson (Sweet et al., 2015);

ii. "Sources of high frequency seismic noise: insights from a dense network of $\sim 250$ stations in northern Alsace (France)", by Jerome Vergne, Antoine Blachet, Maximilien Lehujeur and the EstOF Team (Vergne et al., 2015);

iii. "AlpArray Austria - Illuminating the subsurface of Austria and understanding of Alpine geodynamics", by Florian Fuchs, Götz Bokelmann, Irene Bianchi, MariaTheresia Apoloner, and AlpArray Working Group (Fuchs et al., 2015);

iv. "Introduction of digital object identifiers (DOI) for seismic networks", by Peter Evans, Angelo Strollo, Adam Clark, Tim Ahern, Rob Newman, John Clinton, Catherine Pequegnat, and Helle Pedersen (Evans et al., 2015);

v. "Impact of sensor installation techniques on seismic network performance", by Geoffrey Bainbridge,
Michael Laporte, Dario Baturan, and Wesley Greig (Bainbridge et al., 2015).

\section{Conclusions}

The quality and quantity of presentations made at the EGU2015 SM1.2/GI1.5 session satisfied the expectations of the convener and co-conveners and fit the goals of the European Geosciences Union.

This year, for the first time, the number of presentations at the seismic networks session decreased; however, the same is true for the overall number of presentations of the entire EGU2015 General Assembly. Therefore, the conveners are still confident that the path they followed in organizing such sessions at the yearly EGU General Assembly is a valid one, since there is need in the seismological community worldwide to present and discuss different solutions to common problems in running seismic networks.

Acknowledgements. The authors wish to thank the authors of the EGU2015 SM1.2/GI1.5 session presentations, especially those who made the effort to publish their presentations in these proceedings in Advances in Geosciences. The authors also especially thank the for- 
mer EGU Seismology Division President (and future EGU Seismology Division Vice-President) Charlotte Krawczyk, for her continuous strong support of the seismic networks sessions at the EGU, and welcome the new EGU Seismology Division President Paul Martin Mai.

\section{References}

EGU2011 SM1.3/G3.8/GD3.7/GI-19/TS8.7 Improving seismic networks performances: from site selection to data integration, http: //meetingorganizer.copernicus.org/EGU2011/session/7340 (last access: 6 May 2015), 2011.

EGU2015 SM1.2/GI1.5 Improving seismic networks performances: from site selection to data integration, http://meetingorganizer. copernicus.org/EGU2015/session/17368 (last access: 5 May 2015), 2015.

Bainbridge, G., Laporte, M., Baturan, D., and Greig, W.: Impact of sensor installation techniques on seismic network performance, EGU General Assembly, Vienna, Austria, 12-17 April 2015, EGU2015-14387, 2015.

Evans, P., Strollo, A., Clark, A., Ahern, T., Newman, R., Clinton, J., Pequegnat, C., and Pedersen, H.: Introduction of digital object identifiers (DOI) for seismic networks, EGU General Assembly, Vienna, Austria, 12-17 April 2015, EGU2015-11525, 2015.

Fuchs, F., Bokelmann, G., Bianchi, I., Apoloner, M.-T., and AlpArray Working Group: AlpArray Austria - Illuminating the subsurface of Austria and understanding of Alpine geodynamics, EGU General Assembly, Vienna, Austria, 12-17 April 2015, EGU2015-9965, 2015.
Pesaresi, D.: The EGU2010 SM1.3 Seismic Centers Data Acquisition session: an introduction to Antelope, EarthWorm and SeisComP, and their use around the World, Ann. Geophys.-Italy, 54, 1-7, doi:10.4401/ag-4972, 2011.

Pesaresi, D. and Busby, R.: EGU2013 SM1.4/GI1.6 session: "Improving seismic networks performances: from site selection to data integration", Adv. Geosci., 36, 1-5, doi:10.5194/adgeo-361-2013, 2013.

Pesaresi, D. and Vernon, F.: EGU2012 SM1.3/GI1.7 session: "Improving seismic networks performances: from site selection to data integration", Adv. Geosci., 34, 1-4, doi:10.5194/adgeo-341-2013, 2013.

Pesaresi, D., Clinton, J., and Pedersen, H.: Preface: Improving seismic networks performances: from site selection to data integration (EGU2014 SM1.2/GI3.7 session), Adv. Geosci., 40, 19-25, doi:10.5194/adgeo-1-19-2015, 2015.

Sweet, J., Arias-Dotson, E., Beaudoin, B., and Anderson, K.: Comparative Noise Performance of Portable Broadband Sensor Emplacements, EGU General Assembly, Vienna, Austria, 12-17 April 2015, EGU2015-7985, 2015.

Vergne, J., Blachet, A., Lehujeur, M., and the EstOF Team: Sources of high frequency seismic noise: insights from a dense network of $\sim 250$ stations in northern Alsace (France), EGU General Assembly, Vienna, Austria, 12-17 April 2015, EGU2015-9164, 2015. 